Eugeniusz Cyran and Bogdan Szymanek

John Paul II Catholic University of Lublin

Al. Racławickie 14, 20-950 Lublin, Poland

\title{
PHONOLOGICAL AND MORPHOLOGICAL FUNCTIONS OF PALATALISATION IN IRISH AND POLISH
}

\section{Introduction}

The paper aims to present some basic facts concerning the functions that palatalisation of consonants plays in the phonology and morphology of Irish and Polish. The choice of the two languages is partly due to the apparent similarities that they exhibit. Both languages have more or less obvious palatalisation phenomena, which are not only present in the respective phonological systems in the form of processes and contrasts, but also seem to be used in morphological derivation and inflection. However, the similarities end at the level of generality. A closer look at the linguistic facts from Irish and Polish shows that the two languages differ markedly in detail.

\subsection{Origin of palatalisations and present-day systems}

The term palatalisation is rather broad and ambiguous, as it subsumes two quite disparate linguistic situations. Namely, it may be understood as a dynamic phonetic or phonological process of producing a secondary articulation of a consonant in the context of the following front vowel [i/e] or glide $[\mathrm{j}] .^{1}$ In this sense, palatalisation is allophonic, that is, a context dependent assimilatory process, as may be the case with Irish bith [ $\mathrm{b}^{\mathrm{i}} \mathrm{i}$ ' 'existence', or Polish kiść [kjictc] 'bunch'. ${ }^{2}$ On the other hand, both Irish and

\footnotetext{
${ }_{1}^{1}$ The effects of palatalisation also elude a single-term description. Palatalisation may produce secondary articulation (tongue raising), or create a new primary place - a palatal consonant. It may cause fronting of back consonants, or retraction of front ones. It is often described as softening, but in some cases considered to be instances of palatalisation, for example $[\mathrm{k}]>[\mathrm{t}]$ in Polish, the term is hardly adequate.

2 The phonetic transcription in this paper is that of IPA. The dialect of Irish chosen for this discussion is that of Munster (e.g. Ó Cuív 1975, Sjoestedt 1931, Ó Sé 2000).
} 
Polish seem to show that palatalisation of consonants may also be independent of the context, in which case we are not dealing with a process of palatalisation, but with a genuine lexical property of given consonants, that is, a phonemic distinction. This point can be illustrated by such forms

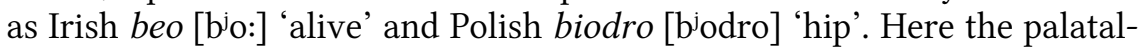
ised consonant is followed by a back vowel and could not have been derived by any process. In our phonological considerations in this paper, we will look at both aspects of palatalisation. Morphologically speaking, on the other hand, it will be shown that mainly the phonemic distinctions are relevant and may be used in morphological processes. It is mainly in this aspect that phonological and morphological functions of palatalisation may coincide.

Historically speaking, the palatalisation of consonants in the two languages looks very similar. It originates from the interaction between consonants and the following front vowels [i, e]. In a system which does not possess the phonological contrast between palatalised and non-palatalised consonants, the fronting / softening of consonants before front vowels may be viewed as allophonic, or phonetic in nature, as schematised below.

(1) $\mathrm{C} \rightarrow \mathrm{C}^{\mathrm{j}} /$ _ $\{\mathrm{i}, \mathrm{e}\}$

It is a phenomenon which can be described as an articulatory anticipation of the following vowel. This was the case in the history of both Irish and Polish. During the phonetic / allophonic stage, phonological conditioning of palatalisation may be observed. For example, only some types of consonants are affected, while others, for example, labials show resistance to this process. Additionally, there is a strict connection between the phenomenon and the context in which it occurs - the process and the context are inseparable.

The status of palatalised consonants may with time be phonologised, that is, they may become contrastive and independent units (phonemes). ${ }^{3}$ One may expect some uniformisation in the consonantal system at this stage. For example, classes of speech sounds which had resisted the process of palatalisation, e.g. labials, now become part of the system of lexical contrasts. Such shifts in status - from allophonic to phonemic - are usually precipitated by developments which lead to the break-up between a given process and the context in which it takes place. One example of this breakup is the situation which arose due to the loss of final syllables in the history of both Irish and Polish.

\footnotetext{
${ }^{3}$ Phonologisation may be followed by another step in the diachronic development, i.e. morphologisation (see, for instance, Janda (2003)). Instances of (partially) morphologised palatalisation will be discussed in what follows.
} 
(2) $\mathrm{C}^{\mathrm{j}} \mathrm{V}_{\mathrm{i}, \mathrm{e}} \rightarrow \mathrm{C}^{\mathrm{j}} /{ }_{-}$\#

In Irish, the consonant took over the role of encoding case or gender distinctions by retaining the palatalisation as part of its own representation. This is visible in the tendency in the Modern Irish lexicon that feminine singular nouns in nominative case end in a palatalised consonant, while masculine singular nouns in nominative case end in a non-palatalised one. ${ }^{4}$ The situation is reversed in the respective genitive cases.

(3)

\begin{tabular}{|l|l|l|l|}
\cline { 2 - 4 } \multicolumn{1}{c|}{} & Nom. sg. & Gen. sg. & Gloss \\
\hline Feminine & $\begin{array}{l}\text { _Ci\# } \\
\text { máthair ['ma:hrr] }\end{array}$ & $\begin{array}{l}\text { _C\# } \\
\text { máthar ['ma:hər] }\end{array}$ & 'mother' \\
\hline Masculine & $\begin{array}{l}\text { C\# } \\
\text { focal['fokəl] }\end{array}$ & $\begin{array}{l}\text { CC\# } \\
\text { focail ['fokll] }\end{array}$ & 'word' \\
\hline
\end{tabular}

A parallel development took place in the history of Polish, and is connected with the loss of the so called jers. There were two types of jers; front $[\mathrm{b}]$ and back [ъ], which mainly originated from the short vowels [i] and [u] respectively. They were schwa-like vowels, which eventually disappeared word-finally, as well as in some word-medial positions. The front jer [b] left a trace on the final consonant, or cluster, in the form of palatalisation.

(4) $\ldots \mathrm{C}^{\mathrm{j}}{ }_{\mathrm{b} \#} \rightarrow \mathrm{C}^{\mathrm{j} \#}$

As mentioned earlier, the loss of final syllables only precipitated the rise of contrastive palatalisation, which is observed in the modern versions of the two languages also in other positions in the word. Consider the following data, which illustrate two important points about the status of palatalisation in Irish and Polish. Firstly, the palatalised consonants in both languages manifest their phonological independence in that they do not require a front vowel context, e.g. Irish ciumhais [k'u:f] 'edge' and Polish biaty [bjawi] 'white' (5a). On the other hand, forms like the Irish tui [ti:] 'straw', and the Polish beli [belij] 'roll, gen.sg.' show that a presence of a front vowel [i, e] is no longer a guarantee of palatalisation of the consonant (5b).

(5)

a. cúis [ku:[] 'reason' ciumhais [k $\mathrm{k}^{\mathrm{j}} \mathrm{u}:[]$ 'edge' bó [bo:] 'cow' beo [bjo:] 'alive'

\section{Polish}

baty [bawi] 'were afraid, fem.pl.'

biaty [b'awi] 'white'

woda $\left[\operatorname{vodo}^{\tilde{w}}\right]$ 'with water'

wioda $\left[\mathrm{v}^{\mathrm{j}} \mathrm{odo}^{\tilde{\mathrm{w}}}\right]$ 'they lead'

${ }^{4}$ This tendency was much more regular in Middle Irish. 

b. tuí [ti:] 'straw'
beli [belij] 'roll, gen.sg.'
tí [tiji:] 'house, gs.'
bieli [ $\left.\mathrm{b}^{\mathrm{j}} \mathrm{el} \mathrm{li}\right]$ 'whiteness, gen.sg.'

It seems that much of the dynamic aspect of palatalisation, which historically speaking makes Irish and Polish very similar systems, has been lost in the modern versions of the two languages. However, some vestigial effects retaining the process-context connection can still be observed and will be mentioned in the respective description of the two languages, and compared in the closing sections of this paper.

Before we begin the descriptions of Irish and Polish with respect to the function of palatalisation in phonology and morphology, let us make a few introductory remarks on the respective consonantal systems.

Irish has two sets of consonants which are typically referred to as velarised and palatalised. For the sake of simplicity and comparison with Polish we will refer to the velarised series as non-palatalised and will not mark this series with any diacritic. The list of Irish consonants of contrastive quality is as follows.

$\begin{array}{llllllllllllllllll}\text { non-palatalised } & p & t & k & b & d & g & f & s & \chi & h & v & \gamma & m & n & j & l & r \\ \text { palatalised } & p^{j} & t^{j} & k^{j} & b^{j} & d^{j} & g^{j} & f^{j} & \int^{5} & \chi^{j} & h^{j} & v^{j} & j & m^{j} & n^{j} & n^{j} & l^{j} & r^{j}\end{array}$

The two qualities listed above are utilised in expressing lexical contrasts, e.g. cúis [ku:f] 'reason' vs. ciumhais [k'u:f] 'edge', as well as in expressing grammatical functions, e.g. fear / fir [far fir'] 'man, nom.sg. / gen.sg.', of which more will be said in the sections below.

In comparison to Irish, the Polish inventory of consonants according to quality is a complex matter. Their listing as contrastive units in general is not difficult given the criteria we used above in (5): if a given segment can stand alone independently of a palatalising context, it is a palatal or palatalised phoneme, if not, it is an allophone. The problem arises once we want to arrange the segments according to their relationship based on palatalisation. Unlike in Irish, where the relationship is simple and pairwise, in Polish the relationships may be multiple, and are almost always a matter of a particular morphological context that they are involved in. Below, following the classification of Gussmann (2007: 5-7), we present all Polish consonants. The underlined speech sounds, e.g. [ $\left.\mathrm{t}^{\mathrm{j}}\right]$ and [c] are not contrastive, but allophonic and will be discussed in more detail in the following section.

${ }^{5}$ We follow the Irish tradition of representing the palatalised version of [s] as [J], which is in fact a palatal sound. 


$$
\begin{aligned}
& \text { bilabial } \quad p \quad \begin{array}{lllllll}
p^{j} & b & b^{j} & m & m^{j} & w
\end{array} \\
& \text { labio-dental } \quad f \quad \mathrm{f}^{\mathrm{j}} \quad \mathrm{v} \quad \mathrm{V}^{\mathrm{j}}
\end{aligned}
$$

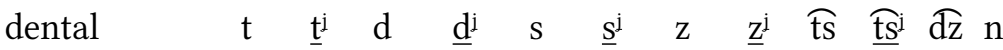

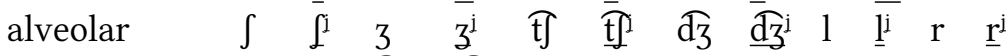

$$
\begin{aligned}
& \text { alveolo-palatal } c \quad \xi \quad \overparen{t_{c}} \quad \frac{\pi}{d \bar{c}} \\
& \text { palatal j } \mathrm{n} \\
& \text { palato-velar } \quad \underline{c} \quad \dot{s} \quad \underline{c} \\
& \text { velar } \quad \mathrm{k} \quad \mathrm{g} \quad \mathrm{x} \underline{\mathrm{n}}
\end{aligned}
$$

The complexity of the Polish consonantal system is obvious. We have palatal consonants like [c, f, ç] which do not enjoy a phonemic status, and palatalised consonants, in the sense of having a secondary articulation, e.g. $\left[\mathrm{p}^{\mathrm{j}}, \mathrm{b}^{\mathrm{j}}, \mathrm{m}^{\mathrm{j}}, \mathrm{f}^{\mathrm{j}}, \mathrm{v}^{\mathrm{j}}\right]$, which are independent units. It should be borne in mind that what is referred to as an independent unit is a segment that exhibits palatalisation without the need to be followed by a front vowel. ${ }^{6}$

Except for the allophonic relationships $\mathrm{C} \sim \underline{\mathrm{C}}^{\mathrm{i}}$, e.g. bok / boki [bok boci] 'side, nom.sg. / nom.pl.', which will be discussed below, any other relationships between segments, which are based on broadly understood palatalisation, are best observed in various alternations connected with particular morphological derivations. Following Gussmann (2007: 125) we will view these alternations as morphophonological palatalisation replacements of segments rather than effects of phonological rules. Next to obvious alternating pairs such as $\left[\mathrm{b} \sim \mathrm{b}^{\mathrm{j}}\right]$, e.g. ryba / rybie $\left[\mathrm{riba} \sim \mathrm{rib}^{\mathrm{j}} \mathrm{e}\right]$ 'fish, nom.sg. / dat. (loc.)sg.' we also observe less obvious relationships which in generative analyses were expressed in terms of different phonological rules of palatalisation. To illustrate this point, let us look at alternations involving the obstruents [t, d, s, z, k, g] in two different morphological contexts, which yield two distinct replacement patterns (Gussmann 2007: 126).

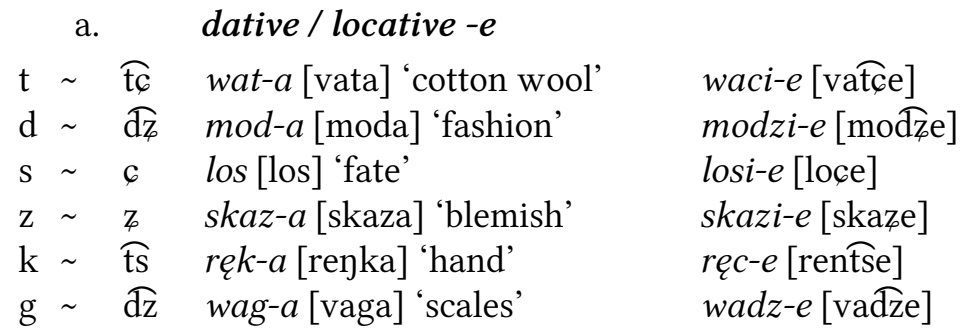

${ }^{6}$ This does not mean that the distribution of such segments is totally free as it is in Irish. For example, the word-final context, known from the phonological tradition as "coda position", excludes all voiced and most palatalised units, leaving only [f, w, t, s, 厄s, $\left.\mathrm{n}, \int, \overparen{\mathrm{t}}\right], 1$, $\mathrm{r}, \boldsymbol{\epsilon}, \overparen{\mathrm{t} \epsilon}, \mathrm{k}, \mathrm{x}]$. The coda context can be extended also to pre-consonantal position, which has similar restrictions. 


\section{b. various other derivational relations}

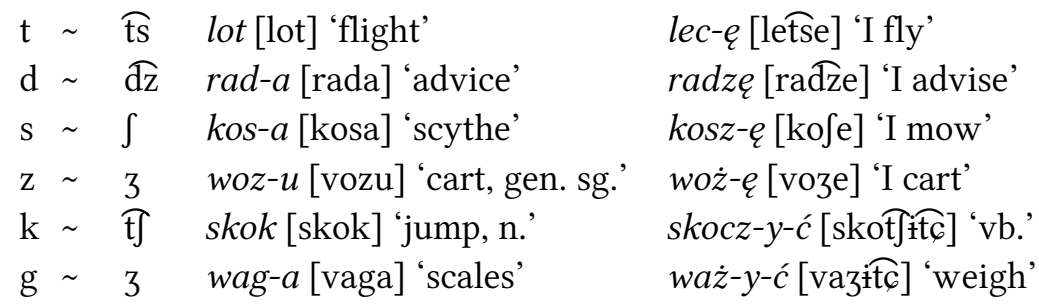

Thus far one thing is clear: due to the break-up of the relationship between effect and context, the alternations shown above cannot be viewed as phonological in nature. The morphological functions of palatalisation are discussed in more detail in the following section devoted to Polish, preceded by a short survey of palatalisation facts, which may be viewed as live phonological phenomena.

\section{Polish}

\subsection{Phonological function of palatalisation}

For decades, Polish palatalisations have attracted the attention of numerous linguists (see, for instance, Gussmann (1978), Rubach (1981)). Most recently, the palatalisation processes in Polish have been explored anew, in two lengthy chapters, by Gussmann (2007; see the relevant earlier literature therein). The contexts are defined as well as the nature and degree of regularity of the processes involved. The status of different types of palatalisation is ascertained, along the phonology - morphophonology dimension. Alternative formal solutions are also reviewed, depending on the requirements of a particular phonological framework: traditional structuralist, derivational generative as well as the recent Government Phonology interpretation. New descriptions of the phenomenon couched in terms of other theoretical frameworks are also available; see, for instance, the studies by Rubach $(2003,2006)$ and Cavar $(2004)$ which draw on the model of Optimality Theory.

What is understood by the term phonological function of palatalisation is simply what palatalisation does in a given phonological system once it is used. One of the functions of palatalisation in phonology, which has been mentioned above in the introduction, is providing lexical contrast. We may refer to it as a static function in that no phonological process can be blamed for the derivation of such segments. In Polish, the most obvious cases of contrastive behaviour of palatalisation can be found in labials: [p - $\mathrm{p}^{\mathrm{j}}$, 
$\mathrm{b}-\mathrm{b}^{\mathrm{j}}, \mathrm{m}-\mathrm{m}^{\mathrm{j}}, \mathrm{f}-\mathrm{f}^{\mathrm{f}}, \mathrm{v}-\mathrm{v}^{\mathrm{j}} .^{7}$ In velars, palatalisation is not contrastive, while the complexity of facts within the class of coronals was signalled in (8) above. Although, as shown in (5) above, palatalisation of consonants is mostly phonemic and independent of the type of vowel that follows, there is strong lexical tendency in native Polish vocabulary concerning the distribution of $[\mathrm{i}-\mathrm{i}]$ and the preceding consonant. In short, the high front $[\mathrm{i}]$ occurs word initially, for example, igta [igwa] 'needle', and follows palatalised consonants $\left(\mathrm{C}^{j i}\right)$, while the retracted [i] is found elsewhere. Namely, it follows non-palatalised consonants $(\mathrm{C} \dot{\mathfrak{t}}) .^{8}$

$$
\begin{aligned}
& \text { bić [bifitc] 'beat' } \\
& \text { być [bïtc] 'be' } \\
& \text { pit [piw] 'he drank' } \\
& \text { pyt [piw] 'dust' } \\
& \text { sin-a [cina] 'blue, fem.sg.' } \\
& \text { syn-a [sina] 'son, gen.sg.' } \\
& \text { mit- } a \text { [miwa] 'nice, fem.sg.' } \\
& \text { myt-a [miwa] 'she washed' }
\end{aligned}
$$

Clearly, we are dealing here with a complementary distribution $\mathrm{C}^{\mathrm{i} i \mathrm{vs}}$. $\mathrm{C} \dot{\mathrm{i}}$, and the question has always been whether it is a distribution of palatalisation on consonants, in which case, palatalisation would be allophonic, or one of vowels $[i-\dot{i}]$, in which case palatalisation would be phonemic. ${ }^{9}$

The same complementary distribution, however, does not concern the other typical "palataliser", that is, the mid vowel [e]. Here, palatalisation of consonants seems to have a clear phonemic status, which yields a number of minimal or near minimal pairs.

$$
\begin{aligned}
& \text { beli [belij] 'roll, gen.sg.' bieli [ } \mathrm{b}^{\mathrm{j}} \mathrm{el}^{\mathrm{j} \mathrm{i}]} \text { 'whiteness, gen.sg.' } \\
& \text { raper [raper] 'rapper' rapier [rapjer] 'rapier' } \\
& \text { pers [pers] 'a Persian (cat)' pierś [p'erc] 'breast' }
\end{aligned}
$$

Thus, on the one hand there is a robust distributional regularity $\mathrm{C}^{\mathrm{j} i} \mathrm{vs.}$ $\mathrm{C} \dot{\mathrm{i}}$ suggesting that palatalisation may be a live phonological phenomenon in Polish (9). This regularity is watered down by the distribution of [e] (10), and completely marred by the distribution of palatalised consonants and other vowels, as shown in (5). For this reason, we treat the above facts as static conditions on phonological representation rather than a live operation of some phonological process.

\footnotetext{
7 Some examples were given in (5) above.

${ }^{8}$ Except velar stops, which generally cannot be followed by the retracted vowel in native Polish vocabulary.

9 A most recent discussion of this dilemma and a rather unorthodox proposal can be found in Gussmann (2007: 32-56). We refrain from making definitive claims as to the status of this distributional regularity, noting only the fact that it concerns only one (two?) vowel(s) in Polish.
} 
Next to the static function of providing contrasts, one may think of a dynamic function of palatalisation, that is phonological phenomena in which this property causes or undergoes changes. In what follows we will concentrate on what remains of the dynamic aspect of palatalisation in Polish phonology. Given the strict criterion for rendering a phenomenon phonological, that is, the obligatory effect - context connection, the dynamic function of palatalisation in Polish is really reduced to two types of phenomena: a) surface palatalisation of velars and coronals in particular contexts, and b) palatal assimilation in consonant clusters.

The most prominent set of data involving dynamic palatalisation concerns velars. Generally, in native Polish vocabulary, velar consonants such as $[\mathrm{k}, \mathrm{g}]$ must be palatalised to $[\mathrm{c}, \mathrm{f}]$ respectively, when followed by front vowels $[\mathrm{i}, \mathrm{e}] .^{10}$

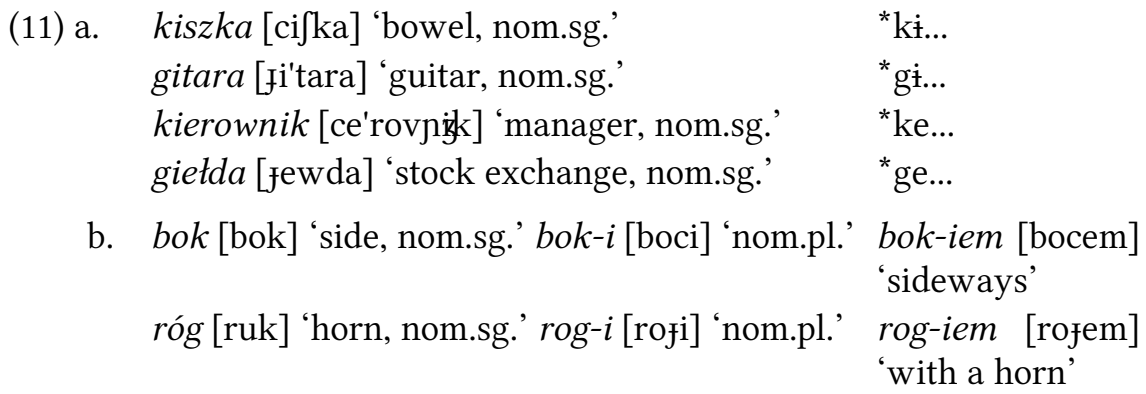

An interesting twist here concerns the behaviour of the retracted vowel $[\dot{i}]$, which cannot follow the velar consonants $\left(\left[{ }^{*} \mathrm{ki},{ }^{*} \mathrm{~g} \dot{\mathrm{j}}\right]\right) .{ }^{11}$ Should such a sequence arise through, for instance, concatenation, it is repaired in that the velars get palatalised to [c, f], and the vowel fronted to [i]. This happens in the masculine plural formation, which, among other ways, is produced by adding the ending [-ì], e.g. dom / dom $-y$ [dom $\sim$ domi $]$ 'house, nom.sg. / nom.pl.'. The plural forms boki and rogi in (11b) are examples of this.

The surface velar palatalisation mentioned above is the only dynamic process of this type which takes place word-internally in native Polish vocabulary. In non-native forms (12a) and across word or morpheme boundaries $(12 \mathrm{~b})$, surface palatalisation is also observed with coronal segments to yield $\left[\mathrm{s}^{\mathrm{j}}, \mathrm{z}^{\mathrm{j}}, \mathrm{t}^{\mathrm{j}}, \mathrm{d}^{\mathrm{j}}, \widehat{\mathrm{ts}}^{\mathrm{j}}, \widehat{\mathrm{t}}^{\mathrm{j}}, \widehat{\mathrm{d}}^{\mathrm{j}}, \mathrm{r}^{\mathrm{j}}\right]$.

${ }^{10}$ We bypass the behaviour of the velar fricative $[\mathrm{x}]$ here.

${ }^{11}$ Except in the surname Kydryński [kidrì̃sci], and the non-native forms like kynolog [kinolok] 'cynologist', and gyros [giros] 'gyros'. 
(12)

a.
Zinus
butik
dinozaur
citroën
Chile
dżihad
rizotto
b. las iglasty
z-integrować
brat i siostra
spod igty
noc idylliczna
smycz Irasiada
wybór idola

[sinus] 'sinus'

[ $\mathrm{z}^{\mathrm{j} i}$ 'dan] 'name'

[butik] 'boutique'

[di'nozaur] 'dinosaur'

[tsij'troen] 'car'

[t]ile] 'country'

[đ3jixat] 'dzhihad'

[ri'zotto] 'risotto'

[las i' i'glasti] 'coniferous forest'

[zinte'grovatc] 'to integrate'

[brat ${ }^{j}$ i costra] 'brother and sister'

[spod ${ }^{j}$ igwi் 'brand new'

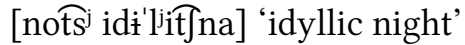

[smitt] ira'cada] 'dog's leash'

[vibur' i'dola] 'choice of idol'

Another area in which a dynamic phonological phenomenon seems to be involved concerns palatal assimilation. Quite expectedly, the facts concerning palatal assimilation, or quality agreement in Polish are very complex, as anything connected with palatalisation (e.g. Gussmann 1999, 2007). First, let us consider the alternations between palatalised and non-palatalised clusters, which depend to a great extent on the morphological operation in question.

$$
\begin{aligned}
& \text { liść } \quad\left[\mathrm{l}^{\mathrm{j} i c t c]}\right] \sim \text { listek [listek] 'leaf, nom.sg./ dim.' } \\
& \text { bliźnie [bliizne] blizna [blizna] 'scar, loc.sg. / nom.sg.' } \\
& \text { prości [proctçi] prosty [prosti] 'simple, masc.pl. / masc.sg.' }
\end{aligned}
$$

Regardless of the actual role of morphology in these alternations, wordinternal sequences of the type ${ }^{*}[\ldots . . \mathrm{ct} . .$.$] , or { }^{*}[\ldots . . \mathrm{stc} . .$.$] are ruled out by the$ phonology of Polish.

To understand the totality of palatal assimilation facts in Polish one would have to take a number of aspects into account. For example, the morphological structure of words, the type of the first consonant $\left(\mathrm{C}_{1}\right)$ in a cluster $\mathrm{C}_{1} \mathrm{C}_{2}$, and the nature of $\mathrm{C}_{2}$ in $\mathrm{C}_{1} \mathrm{C}_{2}$. In what follows, we look only at a fraction of the palatalisation complex and limit the discussion to clusters in which $\mathrm{C}_{1}$ is a spirant [s, z] (Gussmann 1999: 391). This should suffice to demonstrate that generally assimilation in Polish is an active phonological requirement. Morphology may utilise palatalisation in morphophonological replacements, but it is phonology that determines the scope of assimilations. Let us review the facts involving $[s, z]$ as the first element of the cluster. 
Firstly, there is no palatal assimilation of [s, z] in front of non-coronal obstruents, that is, before labial and velar obstruents, for example, skiba [skjiba] 'ridge' (not * [ck $\left.\mathrm{k}^{\mathrm{j} i b a}\right]$ ), spichlerz [spixlef] 'granary' (not * [cpixlef]). This does not mean that a sequence [...c. $\mathrm{p}^{\mathrm{j} . . .}$ ] is ungrammatical in Polish, e.g. śpi [cp $\left.{ }^{\mathrm{j}} \mathrm{i}\right]$ 'he sleeps'. Simply, there is no requirement on palatal assimilation in this context.

Secondly, palatal assimilation takes place before coronals, especially if the two consonants are not separated by a morphological boundary, e.g. ściana [ctçana] 'wall' (not * [sţ̧ana]). If morphological boundary is involved and $[\mathrm{s}, \mathrm{z}]$ act as prefixes or prepositions, then assimilation

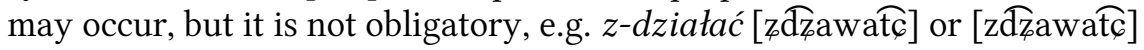
'achieve'.

Thirdly, the effects of assimilation vary before sonorants depending on the position in the word and the voice specification of the spirant. Consider the following data involving initial and medial [sm, zm, sn, zn].

\section{a. word-initial context}

\begin{tabular}{|c|c|c|}
\hline $\begin{array}{l}\text { śmierć } \\
\text { śnieg } \\
\text { zmiana } \\
\text { znicz }\end{array}$ & $\begin{array}{l}\text { [cm'ertc] 'death' } \\
\text { [cnek] 'snow' } \\
\text { [zmjana] 'change' } \\
\text { [znit]] 'candle' }\end{array}$ & 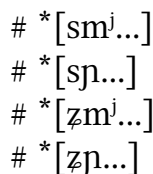 \\
\hline
\end{tabular}

\section{b. word-medial context}

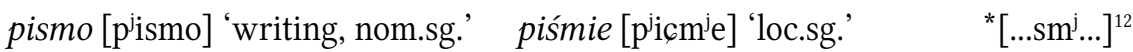

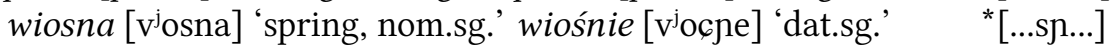
wezmę [vezme] 'I will take' weźmie [vezmie] 'he will take' *[...zm ....] błazna [bwazna] 'fool, gen.sg.' błaźnie [bwazne] 'loc.sg.' *[..zn...]

As we see in (14a), in the word-initial context voice specification of the spirant is responsible for the opposite effects. A voiceless spirant [s] must be assimilated to the following palatalised nasal, while the voiced [z] must not. On the other hand, word-medially both spirants undergo assimilation (14b).

There is an additional set of forms related to (14) and noted in Gussmann (1999: 391), in which [z] may remain unassimilated word-medially if it is preceded by another consonant. Thus, for example, marznqć [marznontç] 'freeze' alternates with marznie [marzne] or [marzne] '(s)he freezes'. Likewise, petznqúc [pewznonţ] 'creep' alternates with petznie [pewzne] or [pewzne] '(s) he creeps'.

${ }^{12}$ Except in non-native vocabulary, e.g. kosmiczny [kos'mitjni] 'space related'. 
Thus, we have seen that palatal assimilation in Polish consonant clusters has diverse phonological conditioning which depends on the nature of the consonants involved, the position within the word, voice specification of the target, and the presence of another consonant in front of the cluster in question. The phonological conditioning of assimilations strongly points to the fact that, next to the surface palatalisation illustrated in (11) and (12) above, these phenomena belong to a dynamic aspect of Polish phonology. They are the main examples of live phonological processes.

In what follows, a survey of the morphological functions of palatalisation is provided. The connection between phonology and morphology consists mainly in using palatalisation based segment replacements signalled in (8) in a number of morphological processes.

\subsection{Morphological function of palatalisation - a continuum?}

Below we shall abstract away from the details of the strictly phonological, theoretical controversies and will focus instead on the diverse linguistic functions attributable to palatalisation effects in Polish.

The following continuum suggests itself, where we see, initially, that there is very little of grammatical function of palatalisation to speak about until, at the other extreme, we are able to recognise and document a significant role played by Polish palatalisations in conveying a variety of morphosyntactic and semantic concepts.

\subsubsection{No grammatical function per se}

In numerous words, Polish palatalisation is an automatic phonetic / phonological effect, obligatorily triggered by the context (i.e., typically, the high front vowel [i], and some occurrences of the front vowel [e]). In this sense, palatalisation is a context-dependent assimilatory process, a case of allophonic variation. As already mentioned above in (11), this phenomenon concerns velar consonants. Some more examples are given below. ${ }^{13}$

(15) Nominative

stok [stok] 'slope'

szlak [Slak] 'trail'

pieróg [pjeruk] 'dumpling'

wymóg [vimuk] 'requirement' wymog-i [vi'mofi]

\section{Instrumental}

stoki-em [stocem] szlaki-em [flacem] pierogi-em [p'e'rofem] wymogi-em [vi'mofem]

${ }^{13}$ Due to space limitations, we shall not be concerned, in what follows, with the interaction between Polish palatalisations and vocalic alternations, notably the problem of vowelzero alternation, as in pies [p'es] 'dog, nom.sg' - ps-a [psa] 'gen.sg.' . 
Alternatively, the presence of a palatalised consonant is a lexical feature of a given root morpheme; cf., in particular, the case of so-called soft stems, where a palatalised segment appears stem-finally, without any conditioning factor that might be held responsible for it: kon [kon] 'horse', ziemi-a [zem'a] 'earth', len [len] 'idler', kość [koctç] 'bone', etc. Crucially, the soft consonant recurs throughout the inflectional paradigm, regardless of the phonological quality of the ending. Consider the declension of kon [kon] 'horse':

\section{(16) The declensional paradigm of the soft-stemmed noun kon' 'horse'}

$\begin{array}{lll} & \text { Singular } & \text { Plural } \\ \text { Nominative } & \text { koń } & \text { koni-e } \\ \text { Genitive } & \text { koni-a } & \text { kon- } i \\ \text { Dative } & \text { koni-owi } & \text { koni-om } \\ \text { Accusative } & \text { koni-a } & \text { koni-e } \\ \text { Instrumental } & \text { koni-em } & \text { koń-mi (koni-ami) } \\ \text { Locative } & \text { koni-u } & \text { koni-ach } \\ \text { Vocative } & \text { koni-u } & \text { koni-e }\end{array}$

In this sense, the occurrence of the palatal(ised) consonant is fully automatic and predictable by virtue of the fact that the noun belongs to the class of soft stems. ${ }^{14}$

However, the lack of any tangible grammatical function for palatalisation may be disputed here: as it encodes the soft-stemmed nature of certain lexemes, it can be viewed as a word-class marker. This information may have important consequences for the morphosyntax; cf., in particular, the special syb-type of underived soft-stemmed nouns which, characteristically, end with a consonant in nom.sg. (like typical masculine nouns) even though they are of feminine gender: sieć [cetc] 'net', dtoń [dwon] 'palm', baśń [bacn] 'fairy tale', pleśn [pleçn] 'mould', kość [koçఢ⿳] 'bone', etc. Hence palatalisation here helps preserve the inflectional integrity of the pattern in question.

In a similar vein, the presence or absence of palatalisation in the lexical representation of feminine nouns determines the choice of the dat./loc. sg. ending so that one can argue that the phonological feature in question has some remote morphological effect. Nouns which end in a hard consonant take the vowel $-e$ (which, as might be expected, induces palatalisa-

${ }^{14}$ However, alternations of the relevant consonant do exist in some derived forms, due e.g. to depalatalisation; cf. koń [kon] > konny [konni], ziemia [zemja] > ziemny [zemni], ziemski [zemsci] (for details, see Gussmann 2007: 34)). Processes of depalatalisation will be left undiscussed in this account. 
tion) while the soft-stemmed nouns take the ending $-i /-y$ (see Gussmann (2007: 106). Both sets are illustrated below:

\begin{tabular}{|c|c|}
\hline \multicolumn{2}{|c|}{ Feminine Noun, hard-stemmed } \\
\hline (Nom.sg.) & (Dat./Loc.sg.) \\
\hline$r y b-a$ [riba] 'fish' & rybi-e $\left[\mathrm{rib}^{\mathrm{j}} \mathrm{e}\right]$ \\
\hline traw-a [trava] 'grass' & trawi-e [trav $\left.{ }^{j} \mathrm{e}\right]$ \\
\hline kos-a [kosa] 'scythe' & kosi-e $[\mathrm{koce}]$ \\
\hline szmat-a [Jmata] 'rag' & szmaci-e $\left[\int \mathrm{matce}\right]$ \\
\hline wod- $a$ [voda] 'water' & wodzi-e [vod̄e] \\
\hline skór-a [skura] 'skin' & skórz-e [skuze] \\
\hline$m a k-a$ [monka] 'flour' & mac-e [montse] \\
\hline nog-a [noga] 'leg' & nodz-e [nođze] \\
\hline$m u c h-a$ [muxa] 'fly' & musz-e [mu $]^{15}$ \\
\hline
\end{tabular}

b. $\quad$ Feminine Noun, soft-stemmed

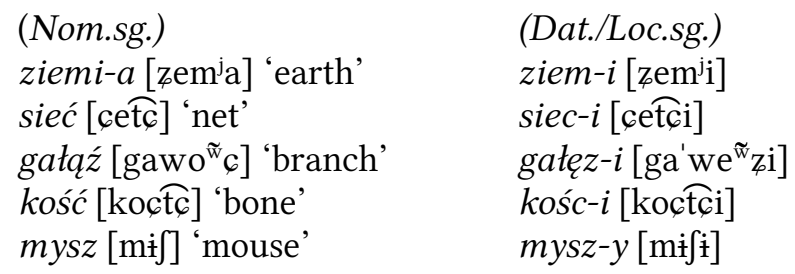

Absence of palatalisation, before a "palatalising vowel", may also be viewed as a lexical property of certain words, stem-internally. However, this is only possible with the vowel [e]; cf. beli [belii] 'roll, gen.sg.', pewny [pevni] 'sure', petny [pewni] 'full', plus numerous loan words ${ }^{16}$ (beż [bef] 'beige', pesymizm [pe'simiism] 'pessimism', welur [velur] 'velour', febra [febra] 'fever', etc). In the latter case (borrowings), the lack of palatalisation may be said to signal the non-native status of individual lexemes. ${ }^{17}$

${ }_{15}$ The synchronic effects of Polish palatalisation are represented not only by phonetically palatalised segments (such as $\left[\mathrm{p}^{\mathrm{j}}, \mathrm{b}^{\mathrm{j}}, \mathrm{m}^{\mathrm{j}}\right]$ etc.) but also by what are termed "functionally soft/palatalised" consonants, which include the palatals $\left[\int, z, \overparen{t}\right.$, $\left.\overparen{d} \bar{z}\right]$ as well as $[\overleftarrow{t s}, \widehat{d z}, 1]$ (see Gussmann (2007: 44, 48)).

${ }^{16}$ With some older loans, the situation is less stable: e.g. geniusz [genjuf] 'genius', generat [ge'neraw] 'general' - [ge ...] side by side with the now obsolete [fe ...].

${ }_{17}$ As illustrated in (12a) above, in the case of coronal obstruents like [t, d, s, $\mathrm{z}$ ], the non-native status of words (lack of phonetic adaptation) is marked by the presence of Surface Palatalisation

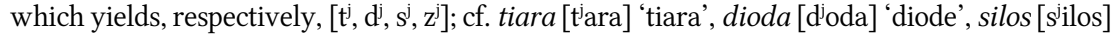
'silo', Zin [zin] 'proper name'. This stands in contrast with the regular native alternations: [t] $\sim[\mathrm{tc}],[\mathrm{d}] \sim[\mathrm{dz}],[\mathrm{s}] \sim[\mathrm{c}],[\mathrm{z}] \sim[\mathrm{z}]$. However, Surface Palatalisation operates as well in native forms when a word boundary separates the consonant and the conditioning segment $(i$ or $j)$; cf. $l o\left[\mathrm{~s}^{\mathrm{j}}\right]$ Ireny 'Irene's fate', lo[s'] Janka 'Janek's fate' (Rubach (2006: 241) and (12b) above). 
Phonologically, because of the partially unpredictable behaviour of consonants before the vowel [e], palatalisation seems to acquire a phonemic status; especially since there are a number of minimal pairs like beli [belij] 'roll, gen.sg.' vs. bieli [bjelij] 'whiteness, gen.sg.', or raper [raper] 'rapper' vs. rapier [rap'er] 'rapier' (cf. (10) above).

\subsubsection{Palatalisation with expressive function (sound-symbolic value)}

Cross-linguistically, palatalisation is found to have a, more or less tangible, sound-symbolic value. For example, Hamano (1994: 154), in a study of "mimetic words" in Japanese, notes the following:

the sound-symbolic association of palatalisation extends over a semantic continuum of "childishness, immaturity, instability, unreliability, uncoordinated movement, diversity, excessive energy, noisiness, lack of elegance, and cheapness". The semantic continuum of palatalisation can be reduced to a basic association of palatalisation of alveolar stops and fricatives with "childishness" or "immaturity." Studies of language acquisition report palatalisation as one of the universal characteristics of early stages of children's language acquisition. It is also reported as one of the commonest devices of baby-talk [...].

These generalisations are corroborated by the Polish data. First, the vocabulary characteristic of child language and baby-talk reveals a number of instances of "consonant replacement in which the stem-final consonant, regardless of its original quality, becomes substituted with the voiceless palatal fricative [c]" (Szpyra 1995: 32) (occasionally, instead of [c], one finds its voiced equivalent, i.e. [द]). Consider the following examples:

$$
\begin{aligned}
& \text { ręk-a [renka] 'hand, arm' } \\
& \text { brzuch [bzux] 'belly' } \\
& \text { wnuk [vnuk] 'grandson' } \\
& \text { nog-a [noga] 'leg' } \\
& \text { Bóg [buk] 'God' }
\end{aligned}
$$

$$
\begin{aligned}
& \text { rasi-a }\left[\mathrm{ro}^{\tilde{\tilde{c}}} \mathrm{ca}\right] \\
& \text { brzusi-o [bzuco] } \\
& \text { wnusi-o [vnuco] } \\
& \text { nózi-a [nuza] } \\
& \text { Bozi-a [boza] }
\end{aligned}
$$

It must be stressed that this sort of expressive replacement has little in common with the regular patterns of palatalisation, which result in distinct and predictable alternations (e.g. [k] will normally alternate with either $[\mathrm{t}]$ ], [ $\mathrm{ts}]$ or [c] but not with [c]). The tendency in question extends beyond the common vocabulary of child language / baby-talk and may be seen at work also in the formation of one type of Polish hypocoristics from personal names (see Szpyra (1995: 32)). For example: 


$\begin{array}{ll}\text { Adam } \text { [adam] } & \text { Adaś [adac] } \\ \text { fan } \text { [jan] } & \text { faś [jac] } \\ \text { Zofi- } a \text { [zof'a] } & \text { Zosi- } a \text { [zoca] } \\ \text { Monik- } a \text { [mo'nika] } & \text { Monisi- } a \text { [mo'nica] } \\ \text { fustyn- } a \text { [jus'tina] } & \text { fustysi- } a \text { [jus'tica] }\end{array}$

Alternatively, the stem-final consonant may undergo ${ }^{18}$ the regular processes of palatalisation, which results in a variety of predictable alternations like the following:

$$
\begin{array}{ll}
\text { Mart- } a \text { [marta] } & \text { Marci- } a \text { [martça] } \\
\text { Wand- } a \text { [vanda] } & \text { Wandzi-a } \text { [vanđ̆́a] } \\
\text { Róż } a \text { [ruza] } & \text { Rózi- } a \text { [ruza] } \\
\text { fan } \text { [jan] } & \text { fani-o } \text { [jajo] }
\end{array}
$$

In the three classes of formations evidenced above, palatalisation has a vaguely expressive function, as it may suggest a variety of meanings like 'endearment', 'affection', 'familiarity', etc. More broadly speaking, the palatalisations in question are claimed to have a morphological rather than purely phonological function (see Kuryłowicz (1987: 217), Szpyra (1995: 31)). Kuryłowicz (1987: 217) attributes the extra expressive value of the palatal(ised) consonants to the fact that, in Polish, these segments, as a class, are phonologically marked with respect to their plain (hard) counterparts.

Another potentially expressive, overtly morphologised category ought to be mentioned here: the diminutive. Polish diminutives are regularly derived by means of the suffixes $-i k /-y k$ and $-e k /-k(a) /-k(o)$. Leaving aside the complicated distribution of these rival formatives, ${ }^{19}$ one should emphasise the fact that, since they incorporate the vowels [i] and [e], their attachment often results in palatalisation of the stemfinal consonants. Thus, the former suffix (which attaches to masculine nouns only) produces various palatalisations of non-velar consonants while the latter one turns the velar obstruents $[\mathrm{k}, \mathrm{g}, \mathrm{x}]$ into the corresponding palatal counterparts: [ $\mathrm{t}$, $\left.3, \int\right]$, respectively. Consider the following forms:

${ }^{18}$ Quite often, Polish hypocoristics are based on a stem which results from the clipping of the final sequence in the name, followed by palatalisation of the last consonant(s), e.g. Edward [edvart] $>E d z i o$ [eđ̄̄o]. We need not be concerned with the clipping process here (see Szpyra (1995) for a detailed description).

${ }^{19}$ See, for instance, Kreja (1989), Malicka-Kleparska (1985), Gussmann (2007: 143). 
(21)
Noun (masc.sg.)
a. $\quad$ sklep [sklep] 'shop' samolot [sa'molot] 'plane' notes [notes] 'notebook'
b. $\quad \operatorname{rak}[\mathrm{rak}]$ 'crayfish'
róg [ruk] 'horn'
dach [dax] 'roof'

\author{
Diminutive \\ sklepik [sklepiik] \\ samolocik [samo'lođ̌iik] \\ notesik [no'tecik] \\ raczek [ratjek] \\ rożek [rozek] \\ daszek [dafek]
}

Moreover, the presence of palatalisation may spread over two adjacent syllables before the final suffix, in cases of so-called double diminutives (see Szymanek and Derkach (2005)); for instance: stót [stuw] 'table' > stol$i k$ [stolik] 'small table' > stol-icz-ek [sto'liit]ek] 'very small table', dach [dax] 'roof' > dasz-ek [dafek] 'small roof' > dasz-ecz-ek [da'fet]ek] 'very small roof'. The cases evidenced above clearly demonstrate that palatalisation is a salient feature of Polish diminutivisation, as it is inextricably interwoven, in most cases, with the morphological operation of suffix attachment. For this reason, palatalisation may be looked upon here as a morphological co-formative which encodes the diminutive function together with the suffix. ${ }^{20}$ Viewed more broadly, Polish palatalisation is a significant expressive device in its own right.

Another piece of evidence for the expressive involvement of palatalisation are certain phenomena from Polish nominal declension, to be more precise: the plural of masculine personal nouns. In brief, the facts are as follows: a major pattern of nominative plural for such nouns is when the suffix $-i /-y$ is added to the stem, producing palatalisation of the stem-final consonant. This may be juxtaposed with the plural of similar nonpersonal nouns, where palatalisation is not triggered, as illustrated below:

(22) Plural of masculine personal nouns (before suffix $-i /-y$ )

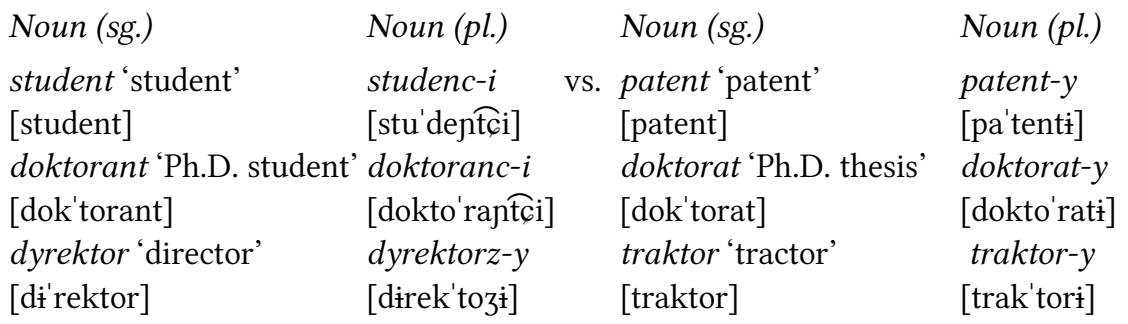

${ }^{20}$ Incidentally, the "diminutive suffix" does not always convey the expected meaning of smallness; it can be used as a general expressive marker only (e.g. socz-ek [sot]ek] < sok [sok] 'juice' or rocz-ek [rot]ek] < rok [rok] 'year' hardly mean 'small juice' or 'small year'). 
Now, crucially, the impersonal pattern is sometimes employed in case of names denoting humans, for expressive effect. That is to say, the plural form shows no trace of palatalisation:

(23) Pejorative / Substandard Plural of masculine personal nouns (before suffix $-i /-y$ )
Noun (sg.)
Noun (pl.)
student [student] 'student'
student- $y$ [stu'denti]
doktorant [dok'torant] 'Ph.D. student'
doktorant-y [dokto'ranti]
dyrektor [di'rektor] 'director'
dyrektor-y [direk'torì]

The above alternative forms, without palatalisation, are strongly suggestive of very colloquial register or dialectal (substandard) speech. In this sense, they are strongly expressive, connoting, for instance, deliberate pejorative downgrading or contempt (in some other forms, the same pragmatic effect may be achieved by replacement of the inflectional suffix; cf. ministr-owie [minis'trov'e] 'ministers' (regular, unmarked form) vs. ministr-y [m'ji'nistri] 'id., expressive').

The following picture of this situation is sketched in Wierzbicka (1988: 455):

Human masculine nouns with a hard stem can take one of the following three endings: $-i,-y$, and -owie. (Human masculine nouns with a soft stem can take either -owie or -e). Of these, $-i$ is neutral, in the sense that it implies nothing beyond 'human male'. The ending -owie is marked, implying, in addition to 'human male', also 'importance' or 'dignity'. The ending $-y$, which is otherwise characteristic of non-human masculine nouns, implies contempt.

Because the key formal difference between the endings $-i$ and $-y$ is that the former regularly induces palatalisation while the latter does not, palatalisation is linked here with the unmarked (regular) forms (cf. the personal forms in (22)), while absence of palatalisation implies marked, expressive usage). The special significance of palatalisation is best visible in nouns ending in $-r$, as in dyrektor $z-y$ [direk'tozi] vs. dyrektor $-y$ [direk'tori] above, since the forms are actually identical in phonetic terms (due to a phonological adjustment of the quality of the final vowel), apart from the stem-final contrast [3] vs. [r].$^{21}$

${ }^{21}$ In the case of noun-stems which end in a velar consonant, the "normal" plural shows a morphonological replacement $[\mathrm{k}]>[\mathrm{ts}],[\mathrm{g}]>[\widehat{\mathrm{dz}}]$, while the "pejorative" plural displays the effect of phonological surface (velar) palatalisation; cf. Polak 'Pole' > Polac-y 'pl.' vs. Polak- $i$ 'pl. pejor.', ginekolog 'gynaecologist' > ginekolodz-y 'pl.' vs. ginekolog-i 'pl. pejor.'. Interestingly, as pointed out in Dressler (2003: 464), the pejorative forms which in- 
To sum up, the presence of stem-final palatalisation in the above nouns seems to be linked to a specific morphosyntactic category, that of human masculine nouns, via their major exponent in the plural, viz. the vowel $-i$. But the significance of this category, as well as the role of concomitant palatalisation, extends beyond noun plurals. Nouns with the $-i$ ending (also -owie) "have a special human-masculine ('virile') agreement, i.e. they impose a special 'virile' form on the verbs and adjectives governed by them." (Wierzbicka (1988: 456)). This may be illustrated with a few examples of inflected adjectives given below, where the items in the lefthand column are the ordinary plural forms (masc./fem./neut.), while the forms on the right are the ones to be used with human-masculine nouns only:

$$
\begin{aligned}
& \text { Adjective, plural } \\
& \text { (masc./fem./neuter) } \\
& \text { stab-e [swabe] 'weak' } \\
& \text { tadn-e [wadne] 'nice' } \\
& \text { gtuch-e [gwuxe] 'deaf' } \\
& \text { cich-e [tcixe] 'quiet, silent' } \\
& \text { star-e [stare] 'old' }
\end{aligned}
$$

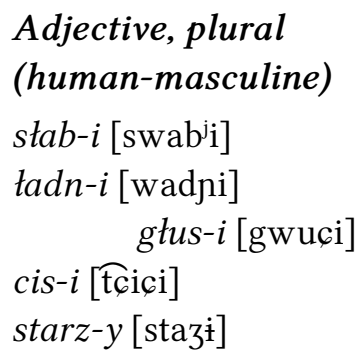

By virtue of agreement, one gets phrases like cis-i mnis- $i$ [tcici mnici] 'silent monks', where palatalisation is a characteristic feature of the stemfinal consonant in both the adjective and the noun, as opposed to the singular form: cich-y mnich [tcixi mnix] 'silent monk'. ${ }^{22}$ But this only happens in phrases headed by 'virile' nouns (cf. cich-y dźwięk [tcixi džvjeyk] 'quiet sound' > cich-e dźwięk-i [tçixe đ̧̆̄ $\left.{ }^{j} e n c i\right]$ 'quiet sounds'). However, when a human-masculine noun is to be used with a pejorative connotation (see above), then its modifying adjective should follow non-human agreement, with no palatalisation on the stem-final consonant of either the noun or adjective. Hence we get cich-e mnich-y [tçixe mnixi] 'silent monks, expr.'.

volve surface palatalisation are more natural, on the parameter of morphotactic transparency, compared to the "normal" noun plurals. This is a bit of a paradox, since the normal plurals appear to be less opaque (thus: more natural) in terms of morphosemantic transparency.

${ }^{22}$ Of course, the $[\mathrm{x}] \sim[\mathrm{c}]$ alternation evidenced here is not the only alternation that the velar spirant [x] participates in. Actually, this pattern is rather limited (cf., for instance, the dubious status of ?sus- $i$ [suci] 'dry, pl., human-masc.' < suchy [suxi] 'dry'), compared to such productive alternations as $[\mathrm{x}] \sim[0]$, well attested by the class of diminutives. But cf. also the nouns derived from the adjectives on the list: gtuch-y [gwuxi] 'deaf' > gtusz-a [gwufa] 'wilderness', cich-y [tçixi] 'quiet, silent' > cisz-a [tciifa] 'silence'. 
Eugeniusz Cyran and Bogdan Szymanek:

Phonological and morphological functions of palatalisation in Irish and Polish

\subsubsection{Palatalisation as a morphological co-formative, due to} morphophonological replacement

As argued in Gussmann (2007: 162-3), some instances of stem-final palatalisation ought to be viewed as being triggered by a special type of process called morphophonological replacement. In fact, according to this view, "the majority of alternations of consonants termed 'palatalisations' are morphophonological replacements of segments" (Gussmann 2007: 125). Such replacements or modifications are lexically governed by special diacritics. ${ }^{23}$

As a case in point, consider a few examples of so-called possessive adjectives in Polish: ${ }^{24}$

\begin{tabular}{|c|c|}
\hline Noun & Derived 'possessive' Adj (fem.sg.nom.) \\
\hline$r y b-a$ [riba] 'fish' & $r y b i-a\left[\mathrm{rib}^{\mathrm{j}} \mathrm{a}\right]$ \\
\hline kot [kot] 'cat' & koci-a [kotça] \\
\hline lis [lijis] 'fox' & lisi-a [lica] \\
\hline szczur [ð fur] 'rat' & 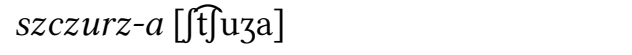 \\
\hline
\end{tabular}

Such phenomena seem to point to the fact that the palatalisations involved in them have a secondary morphological function in that they co-signal, albeit indirectly and in conjunction with overt morphological markers, specific inflectional or derivational categories (like the class of "possessive adjectives" illustrated above). To put it differently, the grammatical status of a form like rybi-e [ribje] (noun: 'fish, dat.(loc.)sg.' or derived adjective: 'fish_, piscine, nom./acc. neuter sg. or nom./acc.pl.') is disambiguated, first of all, on the basis of its syntactic position, agreement relations, etc. (when context is available), but there is a strong hint which comes from the palatal quality of the stem-final consonant that the form in question is an adjective. It ought to be stressed that the adjectival stem always ends in a palatalised $\left[\mathrm{b}^{j}\right]$ while the nominal one has this consonant only in two syncretic case-forms of the singular: the dative and the locative (hence we get a case of inflectional homophony). Another difference is that in the inflected noun rybi-e [ribje] palatalisation operates as a regular phonological process (note the following front vowel) while in the derived adjective it results from a morphophonological mod-

${ }^{23}$ The theory of morphophonological replacements is laid out in detail in Gussmann (2007).

${ }^{24}$ This categorial label is an overgeneralisation, given the fact that the actual meaning of some of the adjectives in question may extend beyond the strictly "possessive" semantics; and so, while in rybi ogon [ribji ogon] 'fish tail' the relation is certainly that of possession (inalienable possession, to be more precise), in rybia tuska [ribja wuska] 'fish scale' the inalienability of possession may be put into question, while in rybie mięso [ribje $\mathrm{m}^{\mathrm{j}} \mathrm{e}^{\tilde{w}_{\mathrm{so}}}$ ] 'fish (meat)' the relation is not possessive at all ('meat from_'). 
ification which takes place even before a back desinential vowel (e.g. rybi-a [rib ${ }^{j}$ a] 'adj, fem.nom.sg.'). Consider the following sentential examples:
a. Datem mięsa rybie.
I-gave meat fish-DAT
'I gave meat to a/the fish.'
b. Rybie mięso jest drogie.
Fish-ADJ meat is expensive
'Fish is expensive.'

Morphologically, the pattern of possessive-adjective formation has been described as a specific case of so-called paradigmatic derivation (or conversion), in the sense that the morphological process shifts the input form from one inflectional paradigm to another. As a result, both the old as well as the new paradigm are characterised by a unique set of desinences. This exhausts the morphological operation in such prototypical instances of paradigmatic derivation as $z t-y$ [zwi] 'bad, evil' $>z t-o$ [zwo] 'evil, n.'. In adjectives like rybi-a $\left[\mathrm{rib}^{\mathrm{j}} \mathrm{a}\right]$, the extra feature of the derivative, apart from paradigm shift, is palatalisation.

Another pattern of this sort is evidenced by a relatively small (unproductive) class of "soft-stemmed" de-adjectival nouns (see Gussmann (2007: 163) for details):

\section{(27) Abstract de-adjectival nouns}

\begin{tabular}{|c|c|c|}
\hline Adjective & Noun (nom.sg) & \\
\hline wi] 'white' & biel [bjel] 'whitenes & $\mathrm{a} \sim \mathrm{e}$ \\
\hline & czerr & $\mathrm{a} \sim \mathrm{e}$ \\
\hline & & $\mathrm{o} \sim \mathrm{e}$ \\
\hline $\begin{array}{l}\text { erwon-y [ [fer'voni] 'red' } \\
\text { it- } y \text { [zuwti ] 'vellow' }\end{array}$ & $\begin{array}{l}\text { czerwień [t]ervjej] 'redness' } \\
\text { źótć [zuwtc] 'vellowness' }\end{array}$ & $\mathrm{o} \sim \mathrm{e}$ \\
\hline
\end{tabular}

The colour terms on the left have their corresponding lexicalised nominalisations which end, characteristically, in a palatalised consonant. Moreover, when we look at their forms in the nominative, palatalisation appears to be the only formal marker of the derivational process (apart from the occasional vowel alternation), since there is no overt ending of the nominative for these feminine nouns. ${ }^{25}$ However, this is a bit misleading: when one examines the com-

${ }^{25}$ However, a few other nouns, which also belong to this pattern, do reveal a vocalic desinence in the nominative; cf. the neuter derivative $z$ drowi-e [zdrov'e] 'health' $<z d r o w-y$ [zdrovi] 'healthy'. 
plete paradigm of the nouns in question, it will transpire that case endings do turn up; e.g. biel- $i$ [bjelii] 'gen./dat.(loc.)sg.', biel-a [ [belo $\left.{ }^{\tilde{}}\right]$ 'instr.sg.', etc. In other words, this group is not really different from the previously mentioned class of soft-stemmed possessive adjectives: again, palatalisation conspires with paradigmatic conversion in ensuring the formal identity of the derivative.

Finally, there are also certain lexical pairs, involving verbs and nouns, like the following: (a) $k \operatorname{rrok}_{\mathrm{N}}[\mathrm{krok}]$ 'step' $>k r o c z-y-c_{\mathrm{V}}$ [krođfitc] 'stride,

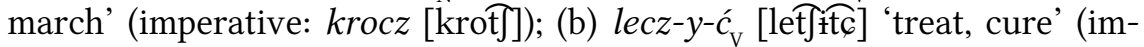
perative: lecz [leđ]]) $>l e k_{\mathrm{N}}[\mathrm{lek}]$ 'drug, medicine'. Arguably, in both patterns, the formal difference between the noun and the imperative is minimal and reducible to presence vs. absence of palatalisation on the root-final consonant. However, there is no direct derivational relationship between these two forms; quite simply - nouns are not derived from imperatives. That is to say, palatalisation hardly operates here, on its own, as a morphological device. What happens, according to traditional accounts, is that both patterns result from conversion (paradigmatic derivation): either a verb is derived from a noun (as in (a)) or, the other way round, a noun is derived from a verb (a verb stem, to be more precise; $\mathrm{cf}$. (b)). ${ }^{26}$

\subsubsection{Palatalisation as a morphological formative?}

To sum up, it seems that this is almost as far as one can go in ascribing morphological function to palatalisation in Polish: the cases of softstemmed denominal adjectives (25) and de-adjectival nouns (27) considered above mark the other extreme on the functional continuum suggested at the outset. One may conclude that while palatalisation is sometimes deceptively prominent, almost suggesting that it is the sole exponent of a particular morphological category, a careful analysis reveals that it never works alone, being supported by overt morphological markers: derivational affixes (cf. diminutivisation), inflectional affixes (cf. the dat.(loc.)sg. ending of nouns like rybi-e [ribje] 'fish'), or paradigm sets (conversion).

A truly morphological function might, perhaps, be attributed to the palatalisation which appears stem-finally in the following "minimal pair" of personal derivatives from the noun fajk-a [fajka] 'pipe' > fajk-arz [fajkaf] 'pipe manufacturer' vs. fajcz-arz [fajtfaf] 'pipe smoker' (note the alternation $[\mathrm{k}] \sim[\mathrm{t}]]$ ). But such cases of semantic contrast where palatalisation alone is responsible are extremely rare. On the other hand, Polish word-

${ }^{26}$ By the same logic, palatalisation alone cannot be held responsible for deriving the noun lot [lot] 'flight' from the verb leci-e-ć [letçetc] 'fly', or from its imperative form leć [letc] - note the vowel alternation in the root as an extra feature. 
formation offers a few more examples where palatalisation of the stem-final consonant, before a derivational suffix, is a matter of free variation, as it does not result in any semantic difference. Consider the following locative formations: bażant [bazant]'pheasant' > bażant-arni-a [bazan'tarna] / bażanci-arni-a [bazan 'tcarna] 'pheasantry', królik [krulik] 'rabbit' > królikarni-a [kruli''karna] / królicz-arni-a [kruli țarna] 'rabbit warren', etc. (see Górska (1985) and Gussmann (2007: 138) for more examples and discussion). Interestingly, such free variation is not found before the inflectional suffixes.

\section{Irish}

\subsection{Phonological function of palatalisation}

There are a number of similarities between Polish and Irish as far as the phonological function of palatalisation is concerned. There are also differences. As mentioned in the introduction to this paper, the origin of palatalised consonants is similar, and so is the present day utilisation of lexical contrasts based on this property (6). The Irish consonantal system of contrasts is rather simple - the consonants are either palatalised or not, $\left[\mathrm{p}-\mathrm{p}^{\mathrm{j}}\right.$, $\left.\mathrm{k}-\mathrm{k}^{\mathrm{j}}, \mathrm{d}-\mathrm{d}^{\mathrm{j}}\right]{ }^{27}$ The distinction is also used to express particular morphological functions, of which more will be said below.

As far as live phonological phenomena are concerned, in which the process-context connection still exists, there are two interesting and interconnected aspects which are worth mentioning. One of them is palatal assimilation in consonant clusters. The other concerns the leftward spreading of the property of palatalisation, which affects vowels. It appears that both phenomena may be two facets of the same process. We begin with assimilation.

Both Irish and Polish exhibit a similar pattern here, which boils down to a general condition that consonant clusters should - as far as the phonological conditioning allows - agree in terms of quality. Sometimes this condition takes the form of static restrictions, sometimes however, a clear process of assimilation can be discerned. The data below show quality agreement in clusters in different positions within the word in Irish. Although we show palatalised clusters only, quite obviously, they may be non-palatalised as a whole too, e.g. gruama [groəma] 'gloomy', scadán [skə'da:n] 'herring', nom.sg., oscail ['oskil'] 'open', or corp [korp] 'body', nom.sg.

${ }^{27}$ We bypass the question if the non-palatalised series should not be also treated as marked. They are characterised by strong velarisation which is particularly audible before front vowels. 


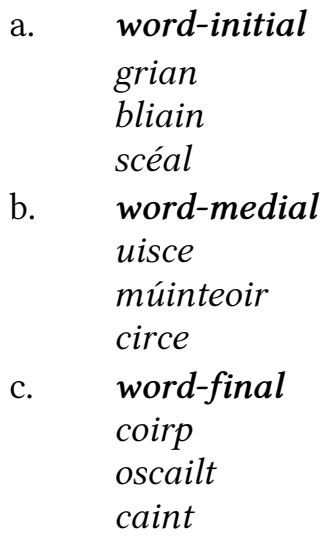

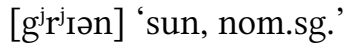

$$
\begin{aligned}
& \text { [bjliın'] 'year, nom.sg.' } \\
& \text { [ } \mathrm{k}^{\mathrm{j} i \mathrm{ial}]} \text { 'story, nom.sg. }{ }^{28} \\
& \text { ['ISk'i I ' water, nom.sg.' } \\
& \text { [mu:n' } \left.{ }^{j^{\prime} t^{j}} \circ: r^{j}\right] \text { 'teacher, nom.sg.' } \\
& \text { ['k } \left.\mathrm{k}^{\mathrm{j}} \mathrm{r}^{\mathrm{j}} \mathrm{k}^{\mathrm{j}} ə\right] \text { 'hen, gen.sg.' } \\
& \text { [koripj] 'body, gen.sg.' } \\
& \text { ['oskil iti'] 'open, } \mathrm{VN}^{29} \\
& \text { [kain'tj] 'talk, VN' }
\end{aligned}
$$

The data above comprise both static lexical forms and cases involving morphologically conditioned alternations between palatalised and nonpalatalised clusters. To the latter group, one may include, e.g. corp [korp]

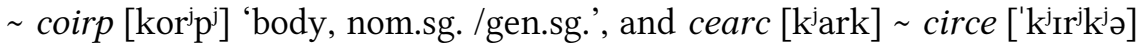
'hen, nom.s.g. / gen.sg.'.

At this point one should ask the question as to the scope of morphological and phonological palatalisation. In other words, whether morphology

\begin{tabular}{|c|c|c|c|}
\hline a. & $\begin{array}{l}\text { an t-ollamh } \\
\text { an t-arán } \\
\text { an t-airgead }\end{array}$ & $\begin{array}{l}\text { [ən 'toləv] } \\
\text { [ən tə'ra:n] } \\
\text { [ən 'tarijigjəd'] }\end{array}$ & $\begin{array}{l}\text { 'the professor' } \\
\text { 'the bread' } \\
\text { 'the money' }\end{array}$ \\
\hline b. & $\begin{array}{l}\text { an } t \text {-im } \\
\text { an } t \text {-iasc } \\
\text { an } t \text {-éan }\end{array}$ & $\begin{array}{l}{\left[\partial n^{j} \mathrm{t}^{\mathrm{j}} \mathrm{i} \mathrm{m}\right]} \\
{\left[\mathrm{n}^{\mathrm{j}} \mathrm{t}^{\mathrm{j}} \mathrm{s} \mathrm{sk}\right]} \\
{\left[\mathrm{n}^{\mathrm{j}} \mathrm{t}^{\mathrm{j}} \mathrm{ian}\right]}\end{array}$ & $\begin{array}{l}\text { 'the butter' } \\
\text { 'the fish' } \\
\text { 'the bird' }\end{array}$ \\
\hline
\end{tabular}
palatalises both consonants in coirp, or just one, while the rest is due to palatal assimilation. ${ }^{30} \mathrm{We}$ will be able to answer this question shortly, after we have seen more examples below.

The following set of data seem to illustrate a dynamic palatal assimilation, that is, a process. It can be observed word-initially in the case of the definite article in front of masculine nouns beginning with a vowel.

The addition of the definite article an in these forms causes the so called $\mathrm{t}$-prefixation. The prefixed [t] may be palatalised or not depending on the phonological structure of the base (Cyran 1997: 142). If, or once the pre-

${ }^{28}$ Recall that [J] is the palatalised form of [s].

${ }^{29} \mathrm{VN}$ stands for Verbal Noun.

${ }^{30}$ Note that in circe $\left[\mathrm{k}^{\mathrm{j}} \mathrm{r} \mathrm{r}^{\mathrm{j}} \mathrm{k}^{\mathrm{j}}\right.$ ] 'hen, gen.sg.' the palatalisation of final consonants is accompanied by a vocalic ending. 
fix is palatalised, the quality also spreads onto the consonant of the definite article (29b).

Finally, Irish also boasts palatal assimilation in which the fundamental principle of adjacency seems to be breeched. Consider the following examples.

$$
\begin{aligned}
& \text { dorn / doirn [dorən dir I In'] 'fist, nom.sg. /gen.sg.' } \\
& \text { doras / dorais [dorəs diri } \mathrm{j}_{\mathrm{I}} \text { ] 'door, nom.sg. /gen.sg.' } \\
& \text { solas / solais [soləs } \sim \text { selist] ] 'light, nom.sg. /gen.sg.' }
\end{aligned}
$$

In the genitive form, palatalisation affects not only the final consonant but also the preceding one. However, the two consonants are separated by a vowel. This does not happen in other forms in which a reduced vowel (schwa) separates the last two consonants, e.g. dealramh / dealraimh [da:rhəv da:rhəv'] 'resemblance, nom.sg. /gen.sg.' or asal / asail [asəl asıli] 'donkey, nom.sg. /gen.sg.'.

A closer look at the facts reveals that in the "irregular" cases in (30) the

\begin{tabular}{|c|c|c|}
\hline doirne & [do:rn'ə] & 'fist, nom.pl. ${ }^{31}$ \\
\hline loirs & [do:r〕ə] & 'door, nom.pl.' \\
\hline soilse & [si::lifə] & 'light, nom.pl.' \\
\hline
\end{tabular}
transparent vowel alternates with zero in the plural.

The facts in (30) can only be explained if we assume that phonologically the two consonants are indeed adjacent and the vowel appearing in the singular and genitive forms is epenthetic. Conversely, we must assume that in dealraimh [da:rhəv'] 'resemblance, gen.sg.' and asail [asili] 'donkey, gen.sg.' the last two consonants are separated by a lexical vowel. Thus, the phonological structure of the word-forms is again crucial here. A similar conditioning was mentioned above concerning the quality of the definite article. Before we determine the scope of morphology and phonology in the phenomenon of palatal assimilation, let us look at some interesting exceptions, which show additional phonological conditioning.

The most spectacular exceptions to the consonant quality agreement concern two instances. The first one is $[\mathrm{r}]$ followed by a homorganic con-

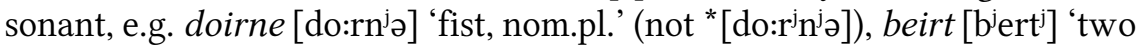
people' (not * $\left.\left[b^{j} e^{j} t^{j}\right]\right)$. The second exception concerns [s] followed by a labial consonant, e.g. speal [spjal] 'scythe, nom.sg.' (not *[ $\left[\mathrm{p}^{\mathrm{j} a l}\right]$ ), sméar [smiar] 'blackberry, nom.sg.' (not * $\left[\mathrm{Jm}^{\mathrm{j} i a r}\right]$ ).

${ }_{31}$ The refusal of [r] to undergo palatal assimilation in homorganic contexts is discussed immediately below. 
It is time to return to our questions concerning the scope of morphological and phonological palatalisation. Firstly, we saw that as a result of morphological operation of genitive formation two final consonants may become palatalised in, e.g. corp [korp] coirp [korjpj] 'body, nom.sg. /gen.sg.'. Sometimes, the palatalisation may be accompanied by an additional vocalic

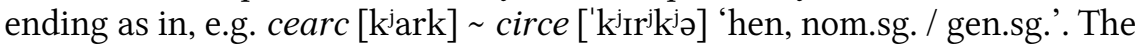
genitive case can also be formed by palatalising a single final consonant, again, with or without an accompanying vocalic element, e.g. fear / fir [far $\sim \mathrm{f}^{\prime} \mathrm{r}^{\mathrm{j}}$ ] 'man, nom.sg. / gen.sg.' and deas / deise [d'as diefə] 'nice, nom.sg. / gen.sg.fem.'. This mini-typology is summarised below. ${ }^{32}$

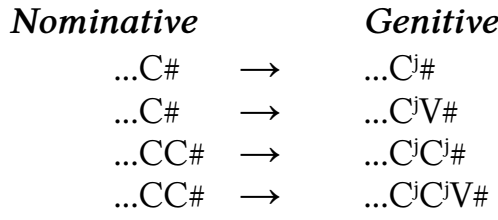

If the entirety of the palatalisation effects in the genitive above is to be blamed on morphology, one would also have to incorporate the examples from (30), e.g. dorn / doirn [dorən] / [dir' ${ }^{j} \mathrm{In}^{\mathrm{j}}$ ] 'fist, nom.sg. / gen.sg.', which exhibit a different pattern, in that the last two consonants are separated by a vowel alternating with zero $\left(\ldots \mathrm{CV}_{0} \mathrm{C} \# \rightarrow \ldots \mathrm{C}^{\mathrm{j}} \mathrm{C}_{0}^{\mathrm{j} \#)}\right)$, and the exceptions mentioned above, e.g. beirt [ $\mathrm{b}^{\mathrm{j}} \mathrm{ert}^{\mathrm{j}}$ ' 'two people'. This would make morphological description of the phenomenon next to impossible. Clearly, we are dealing with strong phonological conditioning on assimilation. Therefore it is prudent to assume that what morphology does is provide the palatalising agent (autosegment), which affects the final consonant of the stem, while phonology determines how far this palatalizing agent will spread leftwards. This way, phonological conditioning may account for all the surface shapes of the morphological operation.

To sum up: phonology in general requires that two consonants, which are phonologically adjacent, agree in quality. This concerns clusters in all positions in the word. The requirement may take a form of static restrictions, especially in contexts where no morphological operations are expected, or suspected. It may also transpire as a live process of palatal assimilation as witnessed in the case of the definite article in (29), the genitive formation in coirp [kor $\mathrm{k}^{\mathrm{j}}$ ] 'body, gen.sg.', and the plural formation

${ }^{32}$ One should bear in mind that depalatalisation is also a valid morphological tool, especially in a language like Irish, in which the palatalised and non-palatalised series are symmetrical. This leads us to the conclusion that there should be a similar typology of genitive formation as depalatalisation. For example, athair / athar [ahir' ahər] 'father, nom.

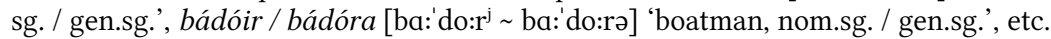


soilse [si:lija] 'light, nom.pl.'. Phonological conditioning of some of the above mentioned phenomena, as well as of the exceptions strongly suggest that morphology cannot be responsible for the palatalisation of an entire cluster. Rather, the morphological operation must be viewed as simple. It merely provides the palatalising agent, or autosegment, alone, e.g. ${ }_{-j}^{-j}$ or in combination with a vocalic element, e.g. ${ }^{-j}$ ə. An alternative interpretation might be that morphology replaces a non-palatalised consonant with a palatalised one, and vice versa, and then the palatalising agent begins to act phonologically. A precise decision in this respect goes beyond the scope of this paper.

Thus, once the palatalising agent is in the phonological representation, it spreads leftwards as far as phonology allows. In consonantal clusters it may fail to affect the preceding consonant, for example, beirt (33b), or not, as in coirp (33a).

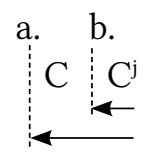

However, this property does not stop at consonants and also affects the preceding vowels, which results in interesting melodic alternations. The phenomenon is also restricted phonologically. Consider the following facts.

(34) The phonological scope of palatalisation (once it's there; whatever the source)

a. $\cos /$ cois

cat / cait

baile

scoil

ciúin

géill

cáis

múinteoir

b. muc/muic

sop / soip

cnoc/ cnoic

olc / oilc

fear / fir

deas / deise

c. dorn / doirn / doirne doras / dorais / doirse solas / solais / soilse

$$
\begin{aligned}
& \text { [kos kof] 'leg, nom.sg. / dat.sg.' } \quad \underline{\text { o } ~ o ~} \\
& \text { [kat } \left.\sim \text { kat }^{j}\right]\left[\mathrm{kI}^{\mathrm{j}}\right] \text { 'cat, nom.sg. / gen.sg.' } \quad \underline{\mathrm{a}} \sim \mathrm{a} \\
& \text { [baljə] 'home, nom.sg.' } \\
& \text { [skolj] 'school, nom.sg.' }
\end{aligned}
$$

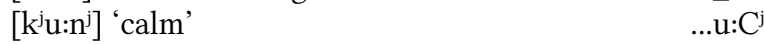

$$
\begin{aligned}
& {\left[\mathrm{g}^{\mathrm{j} e}: \mathrm{l}^{\mathrm{j}]} \text { 'surrender' } \quad \ldots \mathrm{e}: \mathrm{C}^{\mathrm{j}}\right.} \\
& \text { [ka:f] 'cheese' ...a:C }
\end{aligned}
$$

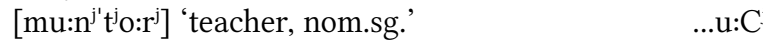

$$
\begin{aligned}
& \text { [muk mik'] 'pig, nom.sg. / dat.sg.' } \quad \mathrm{u} \sim \mathrm{I} \\
& \text { [sop sIp'] 'wisp, nom.sg. / gen.sg.' } \quad \text { o I } \\
& \text { [knok knikj] 'hill, nom.sg. / gen.sg.' } \quad \text { o I }
\end{aligned}
$$

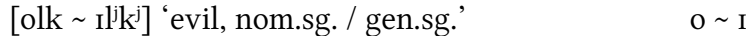

$$
\begin{aligned}
& \text { [f'ar fj Ir'] ' 'man, nom.sg. / gen.sg.' } \quad \text { a I } \\
& \text { [d'as djefə] 'nice, nom.sg. / gen.sg.fem.' } \quad \mathrm{a} \sim \mathrm{e} \\
& \text { [dorən } \sim \text { dirr }^{\mathrm{j}} \mathrm{In}^{\mathrm{j}} \sim \text { do:rn'ə] 'fist, nom.sg. /gen.sg. / nom.pl.' } \\
& \text { [dorəs } \left.\sim \operatorname{dir}{ }^{\mathrm{j}} \mathrm{I} \int \sim \operatorname{do}: \mathrm{r} \int \partial\right] \text { 'door, nom.sg. /gen.sg. / nom.pl.' }
\end{aligned}
$$

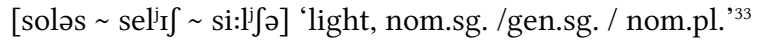

${ }_{33}$ A degree of variation is possible in the latter two forms, which is very interesting. For example, Ó Sé (2000:95) gives the pronunciation [dirrf], with [i] in the first syllable, but wi- 
The forms in (34a) comprise both short and long vowels which resist influence from the following palatalised consonant(s). The resistant short vowels are underlined here to express the fact that they must be lexically marked as opaque. ${ }^{34}$ In (34b), we observe vocalic alternations which are due to palatalisation spreading. It is interesting that having affected these vowels, palatalisation spreading stops before the preceding consonant, if it is lexically unpalatalised. ${ }^{35}$ The data in (34c) show the by now familiar forms in which palatalisation spreads across a vowel which alternates with zero, affects the preceding consonant, and spreads further to affect the first vowel. Here, the interesting point is that the first vowel may be lengthened in the plural, and it is still affected by palatalisation as in, e.g. soilse [si:lijə] 'light, nom.pl. . ${ }^{36}$

The scope of phonological palatalisation spreading is represented graphically below. The ranges (35a-b-c) correspond to the data in (34).

$$
\begin{aligned}
& \text { c. b. a. } \\
& \begin{array}{l:ll:l:l}
\ldots \mathrm{C} & \mathrm{V}_{2} & \mathrm{C} & \mathrm{V}_{1} & \mathrm{C}^{\mathrm{j}} \\
& & & & \leftarrow \mathrm{V}_{1}=\text { opaque = } \underline{\mathrm{a}}, \underline{\mathrm{o}}, \underline{\mathrm{e}},+ \text { lexically long vowels }
\end{array} \\
& \mathrm{V}_{1}=\mathrm{a}, \mathrm{e}, \mathrm{o}, \mathrm{u},+ \text { lengthened vowels } \\
& \mathrm{V}_{1}=\mathrm{V}_{0} \text { (alternates with zero), } \mathrm{V}_{2}=\text { lexically } \\
& \text { short a, o, e, u }
\end{aligned}
$$

Thus in Irish palatalisation spreads further than the preceding consonant and may affect the preceding vowels as well. Phonologically speaking, the function of palatalisation in Irish is similar to that in Polish with respect to the existence of palatal assimilation. However, in Irish palatal assimilation appears to be only a fragment of a more general palatalisation spreading. The phenomenon is subject to phonological conditioning and lexical marking.

thout palatalisation of [r]. He also gives both [solif] and [silis $\mathrm{I}]$, where the type of vowel in the first syllable seems to be correlated with the identification of the following consonant as palatalised or not.

${ }^{34}$ An attempt to explain the parallel behaviour of short opaque and long vowels with respect to palatalisation spreading was made, e.g. in Ní Chiosáin (1991) and in Cyran (1997). The former author proposes that opaque vowels bear full featural specification for backness, as opposed to the alternating vowels. The latter, proposes that opaque vowels are headed, while alternating short vowels and lengthened ones are headless.

${ }^{35}$ In the case of oilc [ $\mathrm{Il}^{\mathrm{l}} \mathrm{k}^{\mathrm{j}}$ ' 'evil, gen.sg.' the onset is missing, and we only observe the vowel change, while in fir [ $\mathrm{f}^{\mathrm{f}} \mathrm{Ir} \mathrm{j}^{\mathrm{j}}$ ' 'man, gen.sg.' and deise [djefə] 'nice, gen.sg.fem.' the first onset is palatalised lexically.

${ }^{36}$ Recall, that $[\mathrm{r}]$ in homorganic contexts resists palatal assimilation. Therefore, the forms doirne [do:rnjə] 'fist, nom.pl.' and doirse [do:rfə] 'door, nom.pl.' do not show any influence of the first vowel. 


\subsection{Morphological function of palatalisation}

In comparison to Polish, the Irish facts concerning the morphological function of palatalisation are much simpler, and the status of palatalisation as an exponent of grammatical categories is more clear and independent. This is mainly due to the fact that the phonemic contrast between palatalised and non-palatalised consonants is symmetrical (6), and a mere replacement of a hard consonant with a soft one, or vice versa, is by and large sufficient for morphological purposes, just as it is for lexical ones in, for example, bó [bo:] 'cow' vs. beo [b'o:] 'alive'.

In the preceding section devoted to the phonological function of palatalisation, we were able to determine also the morphological scope of this phenomenon. Namely, morphology provides the palatalising agent at the right edge of words, with or without an additional overt ending, e.g. ${ }^{-}$each. ${ }^{37}$ In what follows, we will limit ourselves to just a few typical examples of palatalisation and depalatalisation, stressing the strong presence of syncretism.

First of all, in a small group of masculine nouns, both the plural and the genitive singular forms are derived by palatalisation alone (36). This type of syncretism is commonplace in Irish morphology. ${ }^{38}$ Likewise, depalatalisation may also be used syncretically to derive, e.g. genitive singular, e.g. athair / athar [ahirj ahər] 'father, nom.sg. / gen.sg.', or the verbal noun, e.g. coir [kor'] 'tire, v.' vs. cor [kor] 'VN'. Some of these cases will be returned to below.

\begin{tabular}{|c|c|c|}
\hline $\begin{array}{l}\text { Nom.sg. } \\
\text { bád [ba:d] } \\
\text { fear [far] }\end{array}$ & $\begin{array}{l}\text { Nom.pl. } \\
\text { báid [ba:dij] } \\
\text { fir [firir }]\end{array}$ & $\begin{array}{l}\text { Gen.sg. } \\
\text { báid [ba:di] } \\
\text { fir [ }\left[\mathrm{fir}^{\mathrm{j}}\right]\end{array}$ \\
\hline
\end{tabular}

We have seen a fair number of examples of genitive formation in the above sections devoted to phonology. It may also involve adjectives, as in, for example, beag / big [ $\left.\mathrm{b}^{\mathrm{j}} \mathrm{og} \sim \mathrm{b}^{\mathrm{j}} \mathrm{ig} \mathrm{g}^{\mathrm{j}}\right]$ 'small, nom.sg. /gen.sg.masc.', or olc / oilc [olk Ilik'] 'bad, nom.sg. /gen.sg.'. For the sake of completeness we should also remind ourselves of the fact that plural or genitive formation may also involve palatalisation combined with a vocalic suffix, e.g. deas / deise [djas diefə] 'nice, nom.sg. / gen.sg.fem.'. ${ }^{39}$

${ }^{37}$ Or takes away the palatalising agent in what we call depalatalisation.

${ }^{38}$ The dative case may also be formed by palatalising the final consonant as well, e.g. muc / muic [muk mik'] 'pig, nom.sg. / dat.sg.'.

${ }^{39}$ We have also seen earlier that the formative $-{ }^{-} \partial$ is used to derive the nominative plural form as well, e.g. solas / soilse [soləs si:lifə] 'light, nom.sg. / nom.pl.'. 
Another example of derivations which may be viewed as an instance of depalatalisation is found in verbal noun formation. ${ }^{41}$

\begin{tabular}{|c|c|}
\hline Verb & Verbal Noun \\
\hline $\operatorname{coir}\left[\right.$ kor $\left.^{\mathrm{j}}\right]$ & $\operatorname{cor}[\mathrm{kor}]$ \\
\hline $\operatorname{coisc}\left[\mathrm{ko} \int \mathrm{k}^{\mathrm{j}}\right]$ & $\operatorname{cosc}[\mathrm{kosk}]$ \\
\hline cuir $\left[\mathrm{kIr}{ }^{\mathrm{r}}\right]$ & $\operatorname{cur}[\mathrm{kur}]$ \\
\hline toirmisc ['tor' $\left.ә \mathrm{~m}^{\mathrm{j}} \mathrm{I} \int \mathrm{k}^{\mathrm{j}}\right]$ & toirmeasc ['tor'jəm'əsk] \\
\hline
\end{tabular}

To summarise: Irish morphology uses palatalisation on its own and with an additional overt affix in the derivation of grammatical categories. Depalatalisation, is used in the same way, which follows from the symmetry between soft and hard consonants in the phonemic system of contrasts in Irish. Another important feature concerning Irish is the ubiquitous syncretism. Palatalisation and depalatalisation are exponents of more than one grammatical category.

\section{Further comparison and conclusion}

As noted on a few occasions in this paper, phonologically speaking, what makes Irish and Polish similar is the very presence of palatalisation in the consonantal systems, and also a similar origin of these distinctions. Both languages use phonemic contrasts based on this property, although the systems look markedly different. While Irish presents a highly symmetrical set of contrasts, that is, palatalised vs. non-palatalised, Polish boasts a most intricate system of multilayered relations, for example, [t- $\widehat{t} \mathrm{c}_{\mathrm{c}}-$ ts] in lot [lot] 'flight' / leci [letçi] 'he flies' / lece [letse $\left.{ }^{\varpi}\right]$ 'I fly', which are fully used by morphology. Another common feature of the two systems is the presence of palatal assimilations in consonant clusters. Here, substantial differences lie in the respective ways in which the phenomenon is conditioned phonologically. Polish still possesses what looks like a vestigial live palatalisation of consonants by front vowels. This mostly concerns the velar plosives and the high front vowel in native vocabulary, e.g. bok / boki [bok boci] 'side, nom.sg. /nom.pl.'. On the other hand, in Irish the property of palatalisation spreads leftwards further than the preceding consonant, and may affect the preceding vowels as well, e.g. olc / oilc [olk $\left.\mathrm{I}^{\mathrm{l}} \mathrm{k}^{\mathrm{j}}\right]$ 'evil, nom.sg. /gen.sg.'.

${ }^{41}$ See Bloch-Trojnar (2006: 211-213) for a detailed discussion of the intricacies connected with this formation. 
As for morphology, we tried to establish the scope of palatalisation. In Polish, we are dealing with palatal segment replacements as in [t- $\widetilde{t c}_{\mathrm{c}}-$ ts] mentioned above. It may be assumed that, like in Irish, morphology affects the right edge of the word, that is, it replaces only the last consonant, while palatal assimilations are subject to further phonological conditioning. ${ }^{42}$ However, while in Polish we are clearly dealing with entire segment replacements, in Irish there seems to be space for alternative views. Namely, it is possible to assume that morphology only adds the palatalisation property to the right edge, or changes the quality of the last consonant from non-palatalised to palatalised and vice versa. Thus, morphology need not replace the entire segment. This is mostly due to the symmetry of the quality contrasts in Irish. There is, however, one example where segment replacement might be at play. It concerns the $\left[\chi \sim \mathrm{g}^{\mathrm{j}}\right]$ alternation in forms like éadach / éadaigh [iadəx] / [iadig'] 'clothes, nom.sg. / gen.sg.'

A marked difference between the morphological functions of palatalisation in the two languages is the fact that, in Polish, segment replacement is hardly ever a sole exponent of a grammatical function. It is always accompanied by other forms of signalling a change of category: overt suffix, e.g. bok / boczek [bok botjek] 'side, nom.sg. / dim.', or additional modifications, e.g. lot / leć [lot le $\overparen{\epsilon}]$ 'flight' / 'fly, imp.'. In Irish palatalisation may be accompanied by an overt suffix, e.g. deas / deise [d'as $\sim$ d'efə] 'nice, nom.sg. / gen.sg.fem.'does, or not, e.g. cat / cait [kat kat'] 'cat, nom.sg. / gen.sg.'.

Even though some Irish vocalic alternations as in muc / muic [muk mikj] 'pig, nom.sg. / dat.sg.' may superficially resemble Polish lot / leć [lot letc] 'flight' / 'fly, imp.', in that the dative singular form has final palatalisation with concomitant change of the vowel, Irish vocalic alternations have been shown to be a result of a phonological operation and not morphophonological segment replacement, as in Polish lot / leć.

From the functional angle, different sets of lexical and morphosyntactic categories are involved in both languages. For instance, in terms of the inflection / derivation divide, it may be observed that, in Irish, the morphology-related palatalisation co-occurs virtually only with inflectional contrasts (apart from Verbal Noun formation ${ }^{43}$ ), while in Polish its effects, as a

${ }^{42}$ The main argument for this course of action comes from exceptions to palatal assimilation, which appear to be conditioned phonologically, for example, marznać [marznojtc] ] 'freeze' alternates with marznie [marzne] or [marzje] '(s)he freezes', petznać [pewznonfc] ] 'creep' alternates with petznie [pewzne] or [pewzne] '(s)he creeps'

43 See also Doyle (1992: 114-119) for a discussion of consonant palatalisation connected with the diminutive suffix -ín. 
co-formative, reveal themselves both in large areas of the inflectional system as well as in a few patterns of word-formation (e.g. abstract de-adjectival nouns). Additionally - and notably - the Polish palatalisations play a significant role at the "intermediate" level of expressive/evaluative morphology (e.g. diminutives, hypocoristics, pejoratives).

\section{References}

Bloch-Trojnar, M., 2006: Polyfunctionality in Morphology. A Study of Verbal Nouns in Modern Irish, Wydawnictwo KUL, Lublin.

ĆAVAR, M.E., 2004: Palatalisation in Polish. An Interaction of Articulatory and Perceptual Factors, Ph.D. dissertation, University of Potsdam (http://crosbi. znanstvenici.hr/datoteka/232984.DissFinal.pdf).

CyRAN, E., 1997: Resonance Elements in Phonology. A Study in Munster Irish, Folium, Lublin (http://www.kul.lublin.pl/art_526).

DoyLe, A., 1992: Noun Derivation in Modern Irish. Selected Categories, Rules and Suffixes, Redakcja Wydawnictw Katolickiego Uniwersytetu Lubelskiego, Lublin.

DressleR, W.U., 2003: 'Naturalness and morphological change', in: Joseph, B.D. \& Janda, R.D. eds., 461-471.

GóRSKA, E., 1985: 'On the description of 'phonological free variants' in word formation - theoretical implications', in: Gussmann, E., ed., 50-73.

Gussmann, E., 1978: Contrastive Polish-English Consonantal Phonology, Państwowe Wydawnictwo Naukowe, Warsaw.

Gussmann, E., 2007: The Phonology of Polish, Oxford University Press, Oxford.

Gussmann, E., ED., 1985: Phono-Morphology. Studies in the Interaction of Phonology and Morphology, Redakcja Wydawnictw Katolickiego Uniwersytetu Lubelskiego, Lublin.

Hamano, S., 1994: 'Palatalisation in Japanese sound symbolism', in: Hinton, L., Nichols, J., \& Ohala, J.J., eds., Sound Symbolism, Cambridge University Press, Cambridge, 148-157.

JANDA, R.D., 2003: 'Phonologisation' as the start of dephoneticisation - or, on sound change and its aftermath: of extension, generalisation, lexicalisation, and morphologisation', in: Joseph, B.D. \& Janda, R.D., eds., 401-422.

JoSEPH, B.D., \& JANDA, R.D., EDS., 2003: The Handbook of Historical Linguistics, Blackwell, Oxford.

KREJA, B., 1989: Z morfonologii i morfotaktyki wspótczesnej polszczyzny. Part II: Problem dystrybucji przyrostków deminutywnych -ek $i$-ik, Ossolineum, Wrocław, 25-37. 
KuryŁOwICZ, J., 1987: ‘O niektórych właściwościach imion skróconych', in: Studia jezykoznawcze, PWN, Warsaw, 213-218.

Ní Chiosáin, M., 1991: Topics in the Phonology of Irish, Ph.D. dissertation, University of Massachusetts, Amherst, Mass.

Malicka-Kleparska, A., 1985: 'Parallel derivation and lexicalist morphology: the case of Polish diminutivisation', in: Gussmann, E., ed., 95-112.

Ó Cuív, B., 1975: The Irish of West Muskerry. Co. Cork. A Phonetic Study, The Dublin Institute for Advanced Studies, Dublin.

Ó SÉ, D., 2000: Gaeilge Chorca Dhuibhne, Institiúid Teangeolaíchta Éireann, Dublin.

Rubach, J., 1981: Cyclic Phonology and Palatalisation in Polish and English, Wydawnictwa Uniwersytetu Warszawskiego, Warsaw.

RuBACH, J., 2003: 'Polish palatalisation in Derivational Optimality Theory', Lingua 113, 197-237.

Rubach, J., 2006: 'Perspectives on Polish palatalisation', Poznań Studies in Contemporary Linguistics 42, 239-268.

Sjoestedt, M.-L., 1931: Phonétique d'un Parler Irlandais de Kerry, E. Leroux, Paris.

SzPyra, J., 1995: Three Tiers in Polish and English Phonology, Wydawnictwo Uniwersytetu Marii Curie-Skłodowskiej, Lublin.

Szymanek, B., \& Derkach, T., 2005: 'Constraints on the derivation of double diminutives in Polish and Ukrainian', Studies in Polish Linguistics 2, 91110.

WierzBickA, A., 1988: The Semantics of Grammar, John Benjamins, Amsterdam / Philadelphia. 


\title{
Fonološke i morfološke funkcije palatalizacije u irskome i poljskome
}

\begin{abstract}
Sažetak
U ovome radu uspoređuje se status palatalizacije konsonanata u modernom irskom i poljskom unutar fonoloških i morfoloških sustava tih dvaju jezika. Irski i poljski izabrani su među keltskim i slavenskim jezicima zato što oba imaju palatalizirane suglasnike. Jedna funkcija vezana uz razliku palatalizirano/nepalatalizirano leksička je razlika, npr. irski cúis [ku:f] 'razlog' vs. ciumhais [k'u:f] 'rub' i poljski beli [beli] 'svežanj, Gen.sg.' vs. bieli [bjeli] 'bjelina, Gen.sg.' . Fonološki gledano, pojam "palatalizacija" prilično je širok i nejasan, budući da podrazumijeva dva potpuno različita lingvistička slučaja. Naime, može ga se shvatiti kao dinamični fonetski ili fonološki proces u kojem se suglasnik pomiče naprijed ili umekšava kad iza njega slijedi prednji samoglasnik [i/e] ili poluvokal [j]. U tom smislu palatalizacija je alofonska, tj. kontekstualno uvjetovan proces jednačenja, kao što je slučaj s irskim bith [ $\mathrm{b}^{\mathrm{j} \mathrm{i}}$ ] 'postojanje' i poljski bit [bjiw] 'udario je'. S druge strane, čini se da i u irskom i u poljskom palatalizacija suglasnika može biti i neovisna o kontekstu. U tom slučaju ne radi se o procesu, nego o izvornom leksičkom svojstvu suglasnika, tj. o fonološkoj razlici. Ovo se može pokazati na primjerima kao što su irski beo [bjo:] 'živ' i poljski biodro [bjodro] 'bedro'. Budući da iza palataliziranog suglasnika slijedi stražnji samoglasnik, znamo da on nije izazvao palatalizaciju. Drugi dokaz za fonološki status palatalizacije u ovim jezicima pružaju oblici u kojima prisustvo prednjeg samoglasnika ne jamči i palataliziranost suglasnika, npr. irski tuí [ti:] 'slamka' (cf. tí [tij:] 'kuća, gen.sg.') i poljski beli [beli] 'svežanj, gen.sg.' . Moglo bi se zaključiti da postoje znatne fonološke sličnosti između irske i poljske palatalizacije. Ipak, slika se komplicira kad se ta dva sustava detaljnije prouče. Kad se jednom pojavi u fonološkom izrazu riječi, palatalizacija u irskom ima sasvim drugačiju funkciju nego u poljskom. U irskom se palatalizacija ponaša kao nezavisno svojstvo (autosegment) i teži širenju nalijevo zahvaćajući kratke samoglasnike koji prethode (npr. sop / soip [sop / sip ] 'snop / gen.sg'), suglasnike i samoglasnike (npr.. olc / oilc [olk /

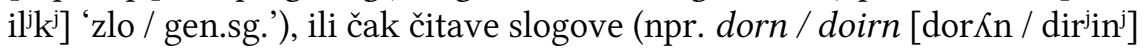
‘šaka / gen.sg.'). Iz toga slijedi da palatalizacija kao proces jednačenja nije potpuno neaktivna. S druge strane, u poljskome postoje tragovi međusobnoga djelovanja suglasnika i samoglasnika koji su praktički ograničeni na velare i neke skupine suglasnika. Cilj je ovog rada odrediti uvjete fonološkoga dosega palatalizacije u irskome i poljskome iz perspektive povijesnog
\end{abstract}


razvoja pojave, ograničenja u distribuciji i sudjelovanja u procesu. Oba jezika uspješno koriste razliku palatalizirano/nepalatalizirano i u odgovarajućim morfološkim sustavima. Povijesni je uzrok ove općenite sličnosti otpadanje završnih suglasnika. U ovom je radu dan pregled različitih leksičkih derivacija i flektivnih paradigmi koje sadrže palatalizaciju.

$\mathrm{S}$ formalne točke gledišta, postoje dva glavna slučaja u kojima razlika palatalizirano/nepalatalizirano ima morfološku funkciju, a svaki od njih ima dvije potkategorije:

1) palatalizacija: a) kao samostalan formant: $\mathrm{C}>\mathrm{C}^{\mathrm{j}}$, npr. irski bád / báid ‘čamac, nom.sg. / nom.pl.', i poljski $r y b-a$ / rybi-a 'riba, nom.sg. / adj.nom. sg.fem.'

b) kao složeni formant: $\mathrm{C}>\mathrm{C}^{\mathrm{j}}+$ samoglasnik, npr. irski deas / deise 'dobar / gen.sg.', i poljski student / studenc-i 'student, nom.sg. / nom.pl.'.

2) depalatalizacija: a) kao samostalan formant: $\mathrm{C}^{\mathrm{j}}>\mathrm{C}$, npr. irski athair / athar 'otac, nom.sg. / gen.sg.'

b) kao složeni formant: npr. poljski liść / list-ek 'listić'.

S funkcionalne točke gledišta, rezultati se u poljskome vide u nekim paradigmama imenske sklonidbe u izvođenju apstraktnih imenica od pridjeva i od posvojnih denominalnih pridjeva, kao i u velikom području ekspresivne tvorbe riječi, itd. Morfološki utjecaj palatalizacije u irskome najbolje se očituje u imenskoj sklonidbi, ali je prisutan i u glagolskoj promjeni i u nekim izvedenicama, npr. u glagolskim imenicama. Potrebne su daljnje lingvističke usporedbe i tipološka istraživanja da bi se u potpunosti razumio status palatalizacije kao poveznice između fonologije i morfologije. U ovome radu pokušali smo postaviti temelje za takvo istraživanje.

Ključne riječi: palatalizacija, morfologija, fonologija, morfofonologija, irski, poljski

Key words: palatalisation, morphology, phonology, morphophonology, Irish, Polish 
